\title{
Perencanaan dan Penentuan Jadwal Induk Produksi di P.T. Arwina Triguna Sejahtera
}

\author{
Muhammad Nasir Sidiq ${ }^{1}$, Akhmad Sutoni ${ }^{2}$ \\ ${ }^{1,2}$ Teknik Industri Universitas Suryakancana \\ Jl. Pasir Gede Raya Cianjur \\ ²tbungsu13@gmail.com
}

Dikirimkan: 10, 2017 . Diterima: 12, 2017. Dipublikasikan: 12,2017.

\begin{abstract}
P.T. Arwina Triguna Sejahtera is a company engaged in the production of molding. Common issues in each company include P.T. Arwina Triguna Sejahtera, is experiencing constraints in planning the production amount according to production capacity. So planned to be created master production schedule so that the cost is not too high. Steps that are done is to start by doing data processing of the past by using demand aggregation, then do the forecasting in accordance with the characteristics of demand. Aggregate procurement planning is carried out for the next 1 (years) period using a permanent employment strategy. Then proceed at the disaggregation stage by using the proportion method, calculating the Master Production Schedule to find out how much quantity of product to produce, and when to start the production. Finally perform the calculation of Rought Cut Capacity Planning to know the balance between the available capacity and the required capacity. Production master schedule obtained, production will be smooth and able to meet the actual demand of 20,000 pcs by adding overtime hours and produce end items as much as 2.368 pcs for deabetamil scoop products, while for featherlock brown plastic products actual demand can be fulfilled. The feasibility of the master production schedule is calculated based on the suitability between Regular Man Hour on production plans, with the amount of time available in the calculated capacity capacity of 17,1360 hours to meet the demand for this year.
\end{abstract}

Keywords- Master Production Schedule; Agregate Production Planning; Rought Cut Capacity Planning; Production System.

\begin{abstract}
Abstrak-P.T. Arwina Triguna Sejahtera merupakan perusahaan yang bergerak dalam bidang produksi moulding. Masalah umum pada tiap perusahaan termasuk P.T. Arwina Triguna Sejahtera adalah mengalami kendala dalam merencanakan jumlah produksi sesuai kapasitas produksi. Sehingga direncanakan dibuat jadwal induk produksi agar biaya tidak terlalu tinggi. Langkah-langkah yang dilakukan yaitu dengan dimulai melakukan pengolahan data masa lalu dengan menggunakan agregasi demand, kemudian melakukan peramalan yang sesuai dengan karakteristik demand. Perencanaan prosuksi agregat dilakukan untuk 1 periode (tahun) ke depan dengan menggunakan strategi tenaga kerja tetap. Kemudian berlanjut pada tahap disagregasi dengan menggunakan metode proporsi, perhitungan Master Production Schedule untuk mengetahui berapa banyak jumlah produk yang harus diproduksi, serta kapan harus memulai produksi tersebut. Terakhir melakukan perhitungan Rought Cut Capacity Planning agar diketahui keseimbangan antara kapasitas yang tersedia dengan kapasitas yang dibutuhkan. Jadwal induk produksi yang diperoleh, produksi akan lancar dan mampu memenuhi actual demand yang ada sebanyak 20,000 pcs dengan cara menambahkan jam lembur dan menghasilkan end item sebanyak 2,368 pcs untuk produk sendok deabetamil, sedangkan untuk produk plastic featherlock s brown permintaan aktual dapat terpenuhi. Kelayakan jadwal induk produksi dihitung berdasarkan kesesuaian antara Regular Man Hour pada rencana produksi, dengan jumlah waktu pada perhitungan kapasitas tersedia yang berjumlah sama yaitu sebanyak 171,360 jam dalam memenuhi permintaan untuk tahun ini.
\end{abstract}

Kata kunci- Jadwal Induk Produksi; Perencanaan Produksi Agregat; Rought Cut Capacity Planning; Sistem Produksi.

\section{PENDAHULUAN}

I.1 Latar Belakang Masalah

P.T. Arwina Triguna Sejahtera, merupakan perusahaan yang bergerak dalam bidang produksi moulding yang menggunakan bahan baku bijih plastik yang berbeda-beda untuk beberapa jenis produknya, 16 bahan baku yang berbeda untuk membuat 104 jenis produk. Dengan beragamnya jenis produk yang harus dipenuhi oleh perusahaan, terkadang perusahaan mengalami kendala dalam pengelolaan bahan baku jenis apa yang harus disiapkan lebih banyak untuk menjaga kestabilan 
produksi yang baik dalam memenuhi order yang akan datang.

Maka dari itu penyesuaian rencana produksi harus benar-benar matang. Terkait dengan kapasitas mesin, dan bahan baku serta ketepatan waktu produksi dalam memenuhi jumlah pesanan (Purchasing Order). Ketepatan dalam perencanaan produksi yang menggunakan bahan baku danproduk yang beragam inisering kali bermasalah dengan P.O. (Purchasing Order) dari perusahaan lain yang beragam dan tidaktentu, hal ini di karenakan P.T. Arwina Triguna Sejahtera menganut sistem make to order. Pihak perusahaan terkadang tidak menyadari bahwa salahsatu bahan baku akan dibutuhkan lebih banyak ketika salah produk tertentu dipesan dengan jumlah yang banyak.

Oleh karena itu dengan membuat rencana produksi diharapkan dapat mengatasi permintaan yang berfluktuasi, terutama jika harus merencenakan jumlah produksi sesuai pesanan dengan menyesuaikan kapasitas produksi, jenis bahan baku, serta kebutuhan tenaga kerja dan meminimalkan ongkos keseluruhan produksi.

\subsection{Perumusan Masalah}

Berdasarkan permasalahan diatas, dapat dirumuskan beberapa permasalahan yaitu:

a. Bagaimana menetukan jumlah produk yang harus di produksi untuk periode berikutnya?

b. Apakah rencana produksi untuk periode mendatang dapat ditanggulangi atau tidak oleh perusahaan dengan ketentuan kemampuan kapasitas produksi perusahaan?

1.3 Tujuan Penelitian

Adapun tujuan dari penelitian ini adalah sebagaiberikut :

a. Mengetahui bagaimana menetukan jumlah produk yang harus di produksi untuk periode berikutnya .

b. Mengetahui rencana produksi untuk periode mendatang dapat ditanggulangi atau tidak oleh perusahaan dengan ketentuan kemampuan kapasitas produksi perusahaan.

Manfaat penelitian berdasarkan pemecahan masalah yang penulis ajukan akan berdampak positif bagi pihak perusahaan, yaitu dapat dipergunakan sebagai dasar perencanaan produksi untuk periode mendatang pada kedua produk yang diteliti. Kemudian perusahan dapat mempergunakan tahapan dan metode yang sama dalam menjalankan kegiatan produksinya untuk produk-produk yang diteliti ataupun produk lain yang diproduksi oleh pihak perusahaan.

\subsection{Pengertian Produksi}

Produksi adalah suatu proses pengubahan bahan baku menjadi produk jadi, sedangkan sistem produksi adalah sekumpulan aktivitas untuk membuat suatu produk, dimana dalam pembuatan produk ini melibatkan tenaga kerja, bahanbaku, mesin, energi, informasi, modal, dan tindakan manajemen. Proses produksi merupakan aktivitas bagaimana membuat produk jadi dari bahan baku yang melibatkan mesin, energi, pengetahuan teknis dan lain-lain.

Sedangkan menurut Baroto dalam [6], perencanaan produksi merupakan bagian dari rencana strategi perusahaan dan dibuat secara hamonis dengan rencana bisnis (busines planning) dan rencana pemasaran (marketing planning). perencanaan produksi dapat diartikan penentuan tingkat atau rate produksi pabrik yang dinyatakan secara agregat atau semua aktivitas bagaimana mengelelola proses produksi tersebut. Perencanaan dan pengendalian produksi merupakan tindakan manejemen yang bersifat absrak (tidak dapat dilihat secara nyata).

Karakteristik dari perencanaan produksi biasanya tidak rinci, hal ini dikarenakan perencanaan produksi dinyatakan dalam kelompokproduk atau famili (agregat). Satuan unit yang dipakai dalam perencanaan produksi bervariasi dari satu pabrik ke pabrik lain.Hal ini bergantung dari jenisproduk seperti : ton, liter, kubik, jam mesin atau jam orang. Kemudian untuk yang tidak standar tergantung pada tipe bisnis apakah make to order atau make to stock. Namun dalam melakukan langkah tersebut faktor konversi harus ditetapkan sebagai alat komunikasi dengan deperatemen lainnya seperti departemen pemasaran danakuntansi bisa berdasarkan satuan menit atau satuan harga yang sudah ditetapkan dan disesuaikan dengan kebutuhan perusahaan. Adapun tingkatan yang lajim dilakukan oleh suatu perusahaan dalam membuat perencanaan produksi adalah sebagai berikut:

a. Proses agregasi demand

b. Peramalan

c. Perencanaan produksi

d. Proses disagregasi

e. Penjadwalan induk produksi

f. RCCP (Rough Cut Capacity Planning)

\subsection{Definisi Peramalan}

Menurut Handoko dalam [5], peramalan adalah suatu usaha untuk meramalkan keadaan dimasa mendatang melalui pengujian keadaan masa lalu. Dalam proses peramalan b dalaiasanya diawali dengan penentuan tujuan, Pengembangan model atau metode peramalan, pengujian model, penerapan model dan revisi dan evaluasi. Revisi digunakan untuk memperbaiki hasil ramalan karena adanya perubahan dalam perusahaan atau lingkungannya. Sedangkan evaluasi digunakan menilai ketepatan pengguanan suatu metode peramalan dengan cara membandingkan 


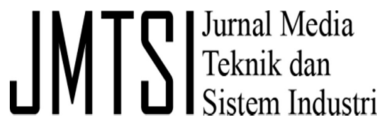

ramalan dengan kenyataan.Adapun pengertian yang berbeda mengenai peramalan sebagai berikut.

Peramalan dalam [7], adalah seni dan ilmu memprediksi peristiwa-peristiwa masa depan. Peramalan bisa jadi berupa prediksi subjektif atau intuitif tentang masa depan dan juga bisa mencakup kombinasi model matematik yang disesuaikan dengan penilaian yang baik oleh manajer .

Sedangkan menurut Subagyo dalam [9], peramalan adalah perkiraan mengenai sesuatu yang belum terjadi sehingga memerlukan penentuan metode peramalan yang paling cocok dengan masalah atau keadaan yang dihadapi. Metode peramalan tidak ada yang paling baik dan selalu cocok digunakan untuk membuat forecast untuk setiap macam hal atau keadaan. Suatu metode mungkin cocok untuk membuat forecast tentang hal atau kedaan ini tetapi tidak cocok untuk membuat forecast hal atau keadaan yang lain. Oleh karena itu kita harus memilih metode yang cocok, yaitu yang bisa meminimumkan kesalahan meramal.

Dari ketiga pendapat diatas dapat disimpulkan bahwa peramalan adalah suatu usaha untuk meramalkan keadaan dimasa yang akan datang berdasarkan keadaan atau data-data di masa lalu. Dengan demikian peramalan merupakan salah satu hal yang harus diperhatikan oleh perusahaan karena dapat menjadi dasar dalam menentukan berapa jumlah barang yang akan diproduksi dan berapa jumlah bahan baku yang dibutuhkan agar produksi dapat berjalan lancar.

\subsection{Teknik-Teknik Peramalan}

Ada banyak tehnik peramalan yang dibuat untuk berbagai keadaan. Hal tersebut dimaksudkan untuk meminimumkan kesalahan forecast, karena suatu teknik peramalan cocok untuk meramal dalam kondisi ini, tetapi tidak cocok untuk meramal pada kondisi lain. Pendapat para ahli mengenai teknik peramalan adalah sama. Sehingga penjelasan hal tersebut dari salah satu ahli sudah mewakili pendapat dari ahli-ahli yang lain. Handoko [5] menjelaskan bahwa ada berbagai teknik peramalan yang tersedia diantaranya adalah sebagai berikut :

1) Teknik Peramalan Kualitatif

Teknik peramalan kualitatif adalah "judgmental" atau berdasarkan estimasi-estimasi dan pendapat-pendapat. Berbagai peramalan kualitatif yang dapat digunakan, secara ringkas dapat diuraikan sebagai berikut :

\section{a. $\quad$ Metode Delphi}

Metode Delphi merupakan tehnik yang mempergunakan suatu prosedur yang sistematik untuk mendapatkan suatu konsensus pendapat dari suatu kelompok ahli.

b. Riset Pasar

Riset pasar adalah peralatan peramalan yang berguna bila ada kekurangan data historik. Tehnik ini secara khusus digunakan untuk meramal permintaan jangka panjang dan penjualan produk baru.

c. Analogi Historik

Peramalan dilakukan dengan menggunakan pengalaman-pengalaman historik dari suatu produk yang sejenis.

d. Konsensus Pane

Gagasan yang didiskusikan oleh kelompok yang akan menghasilkan ramalan yang lebih baik daripada dilakukan oleh seorang saja.

1. Peramalan dengan Rata-Rata Bergerak

Rata-rata bergerak diperoleh melalui penjumlahan dan pencarian nilai rata-rata dari sejumlah periode tertentu, Setiap kali menghilangkan nilai terlama dan menambah nilai baru. Ada dua sifat khusus dari metode moving average atau rata-rata bergerak menurut Subagyo dalam [10] yaitu pertama untuk membuat forecast dengan metode moving average membutuhkan data historis selama jangka waktu tertentu. Kedua semakin lama jangka waktu moving averagesakan menghasilkan moving averages yang semakin halus.

2. Peramalan dengan single exponential smoothing

Menurut Subagyo dalam [10] metode exponential smoothing adalah sebagai berikut: Metode single exponential smoothing adalah perkembangan dari metode moving average. Metode ini menggunakan nilai a yang relatif bebas. Besarnya $a$ antara 0 sampai dengan 1 . Kalau $a$ mendekati 1 berarti data terakhir lebih diperhatikan atau diberi weight lebih besar dari pada data-data sebelumnya.Selain itu metode single eksponential smoothing cocok digunakan untuk meramal hal-hal yang fluktuasinya random (acak).

\subsection{Perencanaan Produksi Agregat}

Perencanaan produksi agregat merupakan salah satu metode dalam perencanaan produksi.Dengan menggunakan perencanaan agregat maka perencanaan produksi dapat dilakukan dengan menggunakan satuan produk pengganti sehingga keluaran dari perencanaan produksi tidak dinyatakan dalam tiap jenis produk (inidividual produk).

Jadi di dalam perencanaan agregat, tidak dihasilkan rencana dalam bentukindividual produk melainkan dalam betuk agregat produk. Penggunaan satuanagregat ini dilakukan mengingat keuntungan-keuntungan yang dapatdiperoleh antara lain: 
a. Kemudahan dalam pengolahan data, dengan menggunakan satuan agregat maka pengolahan data tidak dilakukan untuk setiap individual produk. Keuntungan ini akan semakin terasa jika pabrik tempat perencanaan dilakukan memproduksi banyak jenis produk.

b. Ketelitian hasil yang didapatkan, dengan hanya mengolah satu jenis data produk maka kemungkinan untuk menerapkan metode yang canggih semakin besar sehingga ketelitian hasil yang didapatkan semakin baik.

c. Kemudahan untuk melihat dan memahami mekanisme sistem produksiyang terjadi dalam implementasi rencana yang telah dibuat.

\subsection{Strategi Perencanaan Agregat}

Ada beberapa strategi yang dapat dilakukan untuk melakukan perencanaan yaitu dengan melakukan manipulasi persediaan, laju produksi, jumlah tenaga kerja, kapasitas atau variabel terkendali lainnya.Jikaperubahan dilakukan terhadap suatu variabel sehingga terjadi perubahan lajuproduksi disebut sebagai strategi murni (pure strategy). Sebaliknya, gabungan (mixed strategy), merupakan gabungan perubahan dua atau lebihstrategi murni sehingga diperoleh perencanaan produksi fleksibel.Seandainya datangnya permintaan dari konsumen bersifat rutin dandapat diketahui dengan pasti baik besarnya maupun waktunya makaperencanaan produksi tidak diperlukan lagi.Namun pada kenyataannya polapermintaan ini tidak dapat ditentukan dengan pasti.

\subsection{Jadwal Induk Produksi}

Jadwal induk produksi dalam [1] merupakan rencana tertulis yang memperlihatkan berapa banyak masing-masing jenis yang akan dibuat di dalam suatu periode yang akan datang. Sedangkan pendapat lain memberikan pengertian jadwal induk produksi sebagai berikut

Jadwal induk produksi dalam [8] adalah membuat spesifikasi mengenai apa yang akan dibuat. Jadwal ini harus disesuaikan dengan rencana produksi yang mencakup rencana anggaran, permintaan konsumen, kemampuan teknik, ketersediaan tenaga kerja fluktuasi persediaan kinerja pemasok dan pertimbangan lainnya.

Adapun menurut Handoko dalam [5], jadwal induk produksi ada yang berdasarkan pesanan dan ada yang berdasarkan ramalan penjualan.Pertama, jadwal induk produksi untuk pesanan yaitu jadwal yang dibuat berdasarkan pesanan-pesanan pelanggan untuk berbagai produk.Kedua, jadwal induk produksi untuk persediaan yaitu perusahaan biasanya memproduksi dalam antisipasinya terhadap permintaan dan tidak hanya sekedar hanya memenuhi pesanan pelanggan.

Menurut Vincent Gaspersz dalam [11], Pada dasarnya jadwal produksi induk (master production schedule) merupakan suatu pernyataan tentang produk akhir (termasuk parts pengganti dan suku cadang) dari suatu perusahaan industri manufaktur yang merencanakan memproduksi output berkaitan dengan kuantitas dan periode waktu. Aktivitas Master Production Scheduling (MPS) dalam [11] pada dasarnya berkaitan dengan bagaimana menyusun dan memperbaharui jadwal produksi induk (master production schedule), memproses transaksi dari MPS, dan memberikan laporan evaluasi dalam periode waktu yang teratur untuk keperluan umpan balik dan tinjauan ulang.

Penjadwalan produksi induk dalam [11] pada dasarnya berkaitan dengan aktivitas melakukan empat fungsi utama berikut :

1. Menyediakan atau memberikan input utama kepada sistem perencanaan kebutuhan material dan kapasitas (material and capacity planning/M\&CRP).

2. Menjadwalkan pesanan-pesanan produksi dan pembelian (production and purchase ordes) untuk item-item MPS.

3. Memberikan landasan untuk penentuan kebutuhan sumber daya dan kapasitas.

4. Memberikan basis untuk pembuatan janji tentang penyerahan produk (delivery promises) kepada pelanggan.

Adapun beberapa yang menjadi tujuan penjadwalan produksi induk diantaranya yaitu :

a. Memenuhi target tingkat pelayanan terhadap konsumen.

b. Efisiensi dalam penggunaan sumber daya produksi.

c. Mencapai target tingkat produksi.

Dalam [11] sebagai suatu aktivitas proses, penjadwalan produksi induk membutuhkan lima input utama, yaitu :

1. Data permintaan total merupakan salah satu sumber data bagi proses penjadwalan produksi induk. Data permintaan total berkaitan dengan ramalan penjualan (sales forecasts) dan pesanan-pesanan (orders).

2. Status inventori berkaitan dengan informasi tentang on-hand inventory, persediaan yang dialokasikan untuk penggunaan tertentu(allocated stock), pesanan-pesanan produksi dan pembelian yang dikeluarkan (released production and purchase orders), danfirm planned orders.

3. Rencana produksi memberikan sekumpulan batasan kepada MPS. MPS harus menjumlahkannya untuk menentukan 


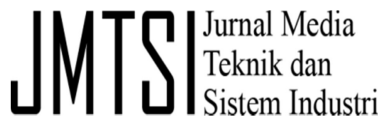

tingkat produksi, inventory, dan sumbersumber daya lain dalam rencana produksi tersebut.

4. Data perencanaan berkaitan dengan aturanaturan tentang lot-sizing yang harus digunakan, shrinkage factor, persediaan pengaman (safety stock), dan waktu tunggu (lead time) dari masing-masing item yang biasanya tersedia dalam file induk dari item (Item Master File).

5. Informasi dari Rough Cut Capacity Planning (RCCP) berupa kebutuhan kapasitas untuk mengimplementasikan MPS menjadi salah satu input bagi MPS. RCCP menentukan kebutuhan kapasitas untuk mengimplementasikan MPS, menguji kelayakan dari MPS, dan memberikan umpan-balik kepada perencana atau penyusun jadwal produksi induk untuk mengambil tindakan perbaikan apabila ditemukan adanya ketidaksesuaian antara penjadwalan produksi induk dan kapasitas yang tersedia.

1.10 Tugas dan Tanggung Jawab Penyusun Jadwal Produksi Induk

Tugas dan tanggung jawab profesional dari penyusun jadwal produksi induk (master production schedule) dalam [11] adalah membuat perubahan-perubahan pada catatan MPS, mendisagregasikan rencana produksi untuk menciptakan MPS, menjamin bahwa keputusankeputusan produksi yang ada dalam MPS itu telah sesuai dengan rencana produksi, dan yang terpenting adalah mengkomunikasikan hal-hal utama dalam MPS itu kepada bagian-bagian lain yang terkait dalam perusahaan.

I.11 Beberapa Pertimbangan dalam Desain MPS

Ketika akan mendesain MPS, perlu diperhatikan beberapa faktor utama yang menentukan proses penjadwalan produksi induk (MPS). Beberapa faktor utama tersebut adalah:

Lingkungan manufakturing sangat menentukan proses penjadwalan produksi induk (MPS). Lingkungan manufakturing yang umum dipertimbangkan ketika akan mendesain MPS adalah make to stock,make to order, dan assemble to order.

Produk-produk dari lingkungan make to stock biasanya dikirim secara langsung dari gudang produk akhir, dan karena itu harus ada persediaan sebelum pesanan pelanggan (customer order) tiba. Hal ini berarti produk akhir harus dibuat atau diselesaikan terlebih dahulu sebelum menerima pesanan pelanggan.

Produk-produk dari lingkungan make to order biasanya baru dikerjakan atau diselesaikan setelah menerima pesanan pelanggan. Seringkali komponen-komponen yang mempunyai waktu tunggu panjang (long lead time) direncanakan atau dibuat lebih awal guna mengurangi waktu tunggu penyerahan kepada pelanggan, apabila pelanggan memesan produk.

Pada dasarnya produk-produk dalam lingkungan assemble to orderadalah make to order product, dimana semua komponen (semifinished, intermediate, subassembly, fabricated, purchased,dan lain-lain) yang digunakan dalam assembly, pengepakan, atau proses akhir, direncanakan atau dibuat lebih awal, kemudian disimpan dalam persediaan guna mengantisipasi pesanan pelanggan.

Berikut ini akan dikemukakan penjelasan singkat berkaitan dengan informasi yang ada dalam MPS seperti di bawah ini :

1. Lead Time adalah waktu (banyaknya periode) yang dibutuhkan untuk memproduksi atau membeli suatu item.

2. On Hand adalah posisi inventori awal yang secara fisik tersedia dalam stock, yang merupakan kuantitas dari item yang ada dalam stock.

3. Lot Size adalah kuantitas dari item yang biasanya dipesan dari pabrik atau pemasok.

4. Safety Stock adalah persediaan tambahan dari item yang direncanakan untuk berada dalam inventori yang dijadikan sebagai persediaan pengaman guna mengatasi fluktuasi dalam ramalan penjualan, pesananpesanan pelanggan dalam waktu singkat, penyerahan item untuk pengisian kembali inventori.

5. Time Bucket pembagian planning periode yang digunakan dalam MPS atau MRP.

6. Time Phase Plan adalah penyajian perencanaan, dimana demand, order, inventory disajikan dalam time bucket.

7. Time Fences adalah batas waktu penyesuaian pesanan.

8. Demand Time fence (DTF) adalah periode mendatang dari MPS dimana dalam periode ini perubahan-perbahan terhadap MPS tidak diijinkan atau tidak diterima karena akan menimbulkan kerugian biaya yang besar akibat ketidaksesuaian atau kekacuan jadwal.

9. Planning Time Fence (PTF) adalah periode mendatang dari MPS dimana dalam periode ini perubahan-perubahan terhadap MPS dievaluasi guna mencegah ketidaksesuaian atau kekacuan jadwal yang akan menimbulkan kerugian.

10. Time Periods For Display adalah banyaknya periode waktu yang ditampilkan dalam format MPS.

11. Sales Plan (sales Forecast) merupakan rencana penjualan atau peramalan penjualan untuk item yang dijadwalkan itu. 
12. Actual Orders merupakan pesanan-pesanan yang diterima dan bersifat pasti (certain).

13. Profected Available Balances (PAB) merupakan informasi proyeksion-hand inventory dari waktu ke waktu selama horizon perencanaan MPS.

14. Available-To-Promise (ATP) merupakan informasi yang sangat berguna bagi departemen pemasaran untuk mampu memberikan jawaban yang tepat terhadap pertanyaan pelanggan.

15. Master Production Schedule (MPS) merupakan jadwal produksi atau manufacturing yang diantisipasi untuk item tertentu.

16. Planning Horizon adalah jangka waktu perencanaan yang digunakan.

I.12 Rought Cut Capacity Planning (RCCP)

Menurut Kusuma dalam [13], untuk melakukan perhitungan kebutuhan kapasitas dengan menggunakan metode Rought Cut Capacity Planning dibutuhkan masukan berupa:

a. Ramalan permintaan dan rencana produksi yang dihasilkan dari proses peramalan, perencanaan agregat serta disagregasi

b. Struktur produk dan bill of material (BOM).

c. Waktu setup dan waktu proses suatu produk disuatu departemen.

d. Jumlah produksi yang ekonomis dari produk tersebut.

\section{Metodologi Penelitian}

\subsection{Model Pemecahan Masalah}

Agar masalah yang ada dapat diselesaikan lebih sistematis, maka penulis membuat tahapan penyelesaian masalah sebagai berikut :

\section{Agregasi Produk}

Agregasi prosduk merupakan proses penyeragaman, sehingga memudahkan untuk membuat perencanaan produksi.

2. Peramalan

Tahap ini adalah tahap melakukan peramalan jumlah permintaan pada periode yang akan datang dengan melihat data jumlah permintaan pada periode sebelumnya.

3. Perencanaan Produksi

Setelah tahap kedua selesai maka kita mendapat data demand agregat untuk periode berikutnya. Data demandinilah yang akan digunakan untuk melakukan perencanaan produksi agregat. Untuk alternatif strategi yang dipilih yaitu metode tenaga kerja tetap, alternatif ini diambil berdasarkan kebijakan perusahaan dalam menjalankan proses produksinya.

4. Disagregasi

Disagregasi adalah proses pengubahan hasil rencana produksi agregat menjadi jumlah yang harus diproduksi untuk setiap end item. Adapun metode yang akan digunakan adalah metode proporsi.

5. Master Production Schedule

Master Production Schedule merupakan satu set perencanaan yang menggambarkan berapa jumlah yang akan dibuat untuk setiap end item. Pada planning period tertentu. Input data yang akan digunakan adalah Out put dari hasil proses disagregasi.

6. Rought Cut Capacity Planning(RCCP)

Rought Cut Capacity Planning dapat didefinisikan sebagai proses konversi dari Rencana Produksi dan atau MPS ke dalam kebutuhan kapasitas yang berkaitan dengan sumber-sumber daya kritis. Rought Cut Capacity Planning digunakan untuk menguji kelayakan kapasitas dari suatu rencana jadwal induk produksi (MPS) sebelum MPS ditetapkan Validasi pada RCCP dikatakan layak apabila kapasitas yang dibutuhkan semuanya dapat dipenuhi oleh kapasitas tersedia.

\subsection{Langkah - Langkah Pemecahan Masalah}

1. Pengumpulan Data

Adapun data - data yang telah dikumpulkan untuk melakukan perhitungan dalam proses pemecahan masalah asalah sebagai berikut:

a. Data umum perusahaan

b. Data permintaan produk selama 2 tahun yaitu dari bulan januari 2015 - desember 2016.

c. Data jumlah tenaga kerja

d. Data jam kerja dan hari kerja

e. Data ongkos yang dikeluarkan:

1. Ongkos kerja normal

2. Ongkos kerja lembur

3. Ongkos simpan

2. Proses Agregasi Demand

Dikarenakan jenis produk (item) lebih dari satu jenis, maka terlebih dahulu harus melakukan agregasi demand yaitu dengan melibatkan faktor konversi sehingga akan menghasilkan data demandagregat, dimana rumus untuk mencari perhitungan tersebut adalah seperti di bawah ini:

a. Faktor Konversi

Untuk faktor konversi agregat ditentukan oleh parameter jenis end item produk tertentu. Proses konversi agregat produk dapat dilakukan dengan perhitungan sebagai berikut:

Faktor Konversi $=\frac{\text { harga prooduk termurah }}{\text { harga produk termahal }}$

Parameter yang digunakan adalah waktu baku yang terbesar, Dan yang menjadi penyebut adalah waktu baku yang terkecil sebagai acuan dari produk tertentu.

\section{b. Demand Agregat}

Untu mencari demand agregat, maka data permintaan tiap item dikalikan dengan faktor konversinya masing-masing, perhitungannya adalah sebagai berikut : 


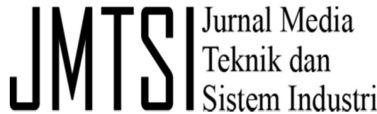

Demand Agregat $=$ data demand $\mathrm{x}$ faktor konversi

c. Plot Data

Melakukan plot data agregat sesuai dengan data permintaan yang sebelumnya telah diagregasi.

3. Forcasting (peramalan)

Setelah melakukan proses agregasi, kemudian langkah selanjutnya adalah melakukan proses peramalan untuk permintaan periode yang akan datang. Dimana data aktual yang akan dijadikan input data agregat adalah data demand agregat pada periode sebelumnya yang telah di agregasi.

Dalam menentukan metode peramalan yang akan digunakan penulis harus memplot data yang ada terlebih dahulu agar dari hasil plot data tersebut diketahui jenis pola data yang ada, apakah mengikuti pola horizontal, pola musiman, pola siklik, atau pola yang sesuai dengan kondisi aktual yang ada. Dari beberapa metode yang ada, penulis harus memilih salah satu metode yang paling tepat yaitu metode yang menghasilkan nilai error tekecil, dan error yang penulis tentukan adalah rata-rata kesalahanprioritasyang paling kecil.

4. Perencanaan Produksi

Perencanaan Produksi yang akan penulis lakukan adalah perencanaan Produksi dengan menggunakan strategi tenaga kerja tetapproduksi konstan. Adapuntahapan-tahapannya adalah sebagai berikut :

a. Menghitung Rencana Produksi

$\Sigma \mathrm{RP}=\Sigma$ demand + safety stock - inventory awal

b. Menghitungreguler man hour (RMH)

$\mathrm{RMH}=$ jmltenagakerja $\mathrm{x}$ harikerja $\mathrm{x}$ jam kerja

c. Menghitung Produksi Normal / Unit Production Regular Time(UPRT)

Produksi Normal $=\frac{\mathrm{RMH}}{\text { Waktubaku }} \mathrm{X}$ Persen produktivitas

d. Menghitung kapasitas Produksi Normal (UPRT)

KAP produksi normal $=\underline{\text { jml tenaga kerja } \mathrm{x} \text { hari kerja } \mathrm{x} \text { jam kerja }}$ Waktu baku

e. Menghitung Inventory akhir Inventory akhir = UPRT- demand

f. Menghitung produksi lembur / Unit Production Over Time (UPOT)

Menghitung unit produksi over time (UPOT), atau lembur dilakukan jika produksi normal Unit Production Regular Time (UPRT) tidak dapat memenuhi permintaan. Dalam kata lain jika UPRT lebih besar dari demand (UPRT > demand) tidak perlu melakukan Unit Production Over Time (UPOT).

$\mathrm{UPOT}=\mathrm{UPRT}-$ demand + Inventory akhir g. Menghitung kapasitas produksi over time (UPOT)

Kapasitas UPOT $=25 \%$ x UPRT

h. Menghitung Subkontrak

Subkontrak dilakukan apabila kapasitas demand tidak terpenuhi meski sudah melakukan lembur (UPOT).

Subkontrak = Demand - inventory awal UPRT - UPOT

i. Menghitung kapasitas Subkontrak

Kapasitas Subkontrak $=50 \%$ x UPOT

j. $\quad$ Menghitung Total Produksi

Total Produksi $=$ Produksi Normal $($ UPRT $)+$ Produksi over time (UPOT)

k. Menghitung ongkos produksi normal

Tot. ongkos UPRT $=\sum$ UPRT $\mathrm{x}$ ongkos UPRT

1. Menghitung ongkos produksi lembur

Tot. ongkos UPOT $=\sum$ UPOT $\mathrm{x}$ ongkos UPOT

m. Menghitung ongkos simpan

Tot. ongkos simpan $=\sum$ inventoriakhir $\mathrm{x}$ ongkos inventori akhir

n. Menghitung ongkos total produksi

Total produksi ongkos $=$

$=$ ongkos produksi normal + ongkos produksi lembur + ongkos simpan

\subsection{Proses Disagregasi}

Proses Disagregasi ini menggunakan metode Proporsi, Proses Disagregasi dilakukan setelah melakukan rencana produksi agregat sebagai input dasar bagi Master Production Schedule pada Master Schedule. Tahapan-tahapan dalam proses Disagregasi ini adalah sebagai berikut :

a. Menghitung \% Proporsi

$$
\% \text { Proporsi }=\frac{\text { Total demand agregat end item }}{\text { Total demand agregat }} \times
$$
$100 \%$

b. Menghitungforecast demand

End item $_{\mathrm{t}}=$ demand aktual X \% Proporsi

c. Menghitung MasterSchedule

$\mathrm{MS}=\frac{\text { Total Produksi } x \text { proporsi rata-rat end item }}{}$

2.4 Penjadwalan Produksi Induk (Master Production Schedule)

Setelah proses disagregasi kemudian dilanjutkan pada proses pembuatan jadwal induk produksi dengan format sebagai berikut :

a. Nama dan Nomor item

b. Periode

c. Ramalan Kebutuhan, informasi di dapat dari bagian pemasaran berupa estimasi terhadap kuantitas end item yang akan terjual pada setiap periode.

d. Pesanan Konsumen (Custumer Order/Actual Order), berupa pesanan konsumen yang sudah diterima sehingga statusnya pasti. 
e. Proyeksi persediaan (on hand) atau Projected Avaliable Balance, merupakan proyeksi on hand dari waktu ke waktu yang menunjukan status inventory yang diproyeksilkan pada akhir dari setiap periode.

f. Jumlah yang bisa dijanjikan (avaliable promise), merupakan alat yang digunakan untuk menjanjikan jumlah yang bisa dipesan oleh konsumen.

g. Jadwal produksi (MasterSchedule) adalah keputusan tentang kuantitas yang akan diproduksi dan saat produk itu memasuki stock.

\subsection{RCCP (Rought Cut Capacity Planning)}

Tahapan-tahapan yang harus dilakukan dalam proses RCCP adalah sebagai berikut :

a. Menentukan Routhing Sheet

Standar Hours $=\frac{\text { Run Time }+\left\{\left\{\frac{\text { Setup Times }}{\text { lot size }}\right\}\right.}{3600}$

b. Menentukan RCCP

$\mathrm{RCCP}=$ MasterSchedulex Standart Hours

c. Menentukan kapasitas yang dibutuhkan

Menjumlahkan total RCCP dari aetiap Work Station (WS).

d. Menentukan kapasitas yang tersedia

Kapasitas tersedia $=$ Jam kerja $\mathrm{x}$ Hari kerja $\mathrm{x}$ Tenaga kerja

2.6 Kerangka Pemecahan Masalah

Kerangka pemecahan masalah dalam penelitian ini seperti yang tercantum pada gambar 1.

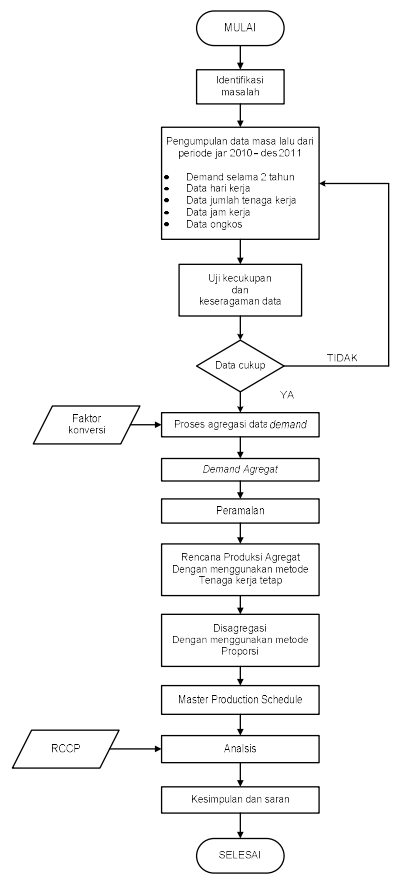

Gambar.1 Diagram kerangka pemecahan masalah

\section{HASIL PENELITIAN}

3.1 Data Permintaan Produk

Data permintaan produk seperti yang tercantum pada tabel I di bawah ini.

TABEL I

DATA PERMINTAAN SENDOK DEABETAMIL DAN PLASTIK

\begin{tabular}{|c|c|c|c|c|c|}
\hline \multirow[b]{2}{*}{ No } & \multirow[b]{2}{*}{ PEROODE } & \multirow[b]{2}{*}{ BULAN } & \multicolumn{2}{|c|}{ DATA DEMAN PRODUK } & \multirow[b]{2}{*}{ Total } \\
\hline & & & SENDOKDEABETAMIL & $\begin{array}{l}\text { PLASTIKFEATHERRLCKK } \\
\text { SBROWN }\end{array}$ & \\
\hline 1 & \multirow{12}{*}{$\begin{array}{l}2 \\
0 \\
1 \\
5\end{array}$} & JAN & 40,000 & 1000000 & $1,040,000$ \\
\hline 2 & & $\mathrm{FEB}$ & 40,000 & 1000000 & $1,040,000$ \\
\hline 3 & & MAR & 40,000 & 1000000 & $1,040,000$ \\
\hline 4 & & APR & 20,000 & 800000 & 820,000 \\
\hline 5 & & MAY & 20,000 & 1000000 & $1,020,000$ \\
\hline 6 & & IUN & 40,000 & 1000000 & $1,040,000$ \\
\hline 7 & & JUL & 20,000 & 1000000 & $1,020,000$ \\
\hline 8 & & AUG & 40,000 & 1000000 & $1,040,000$ \\
\hline 9 & & SEP & 20,000 & 1800000 & $1,820,000$ \\
\hline 10 & & OCT & 20,000 & 1000000 & $1,020,000$ \\
\hline 11 & & NOV & 20,000 & 500000 & 520,000 \\
\hline 12 & & DEC & 20,000 & 1500000 & $1,520,000$ \\
\hline 1 & \multirow{12}{*}{$\begin{array}{l}2 \\
0 \\
1 \\
6\end{array}$} & JAN & 20,000 & 1000000 & $1,020,000$ \\
\hline 2 & & $\mathrm{FEB}$ & 40,000 & 50000 & 540,000 \\
\hline 3 & & MAR & 20,000 & 500000 & 520,000 \\
\hline 4 & & APR & 20,000 & 500000 & 520,000 \\
\hline 5 & & MAY & 20,000 & 1000000 & $1,020,000$ \\
\hline 6 & & JUN & 20,000 & 1500000 & $1,520,000$ \\
\hline 7 & & JUL & 20,000 & 500000 & 520,000 \\
\hline 8 & & AUG & 20,000 & 1000000 & $1,020,000$ \\
\hline 9 & & SEP & 40,000 & 2000000 & $2,040,000$ \\
\hline 10 & & OCT & 25,000 & 1000000 & $1,025,000$ \\
\hline 11 & & NOV & 20,000 & 2000000 & $2,020,000$ \\
\hline 12 & & DEC & 40,000 & 1000000 & $1,040,000$ \\
\hline & & & 645,000 & $25,100,000$ & $25,745,000$ \\
\hline
\end{tabular}

Sumber : Data perusahaan PT Arwina Triguna Sejahtera

Adapun plot data permintaan seperti ercantum pada gambar 2 di bawah ini.

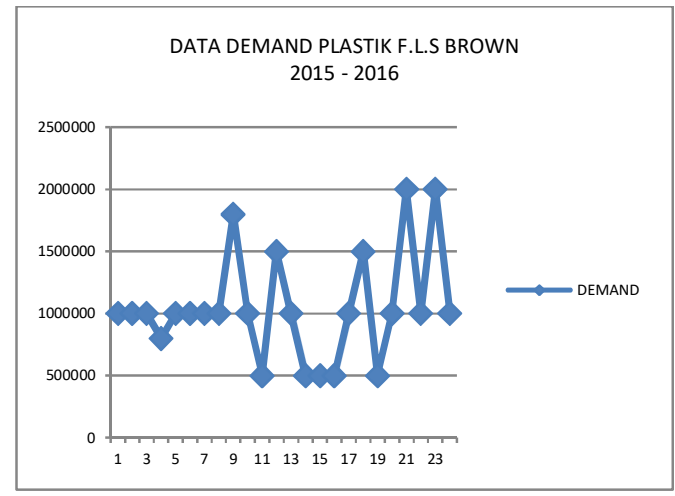

Gambar 2. Plot data demand sendok deabetamil 


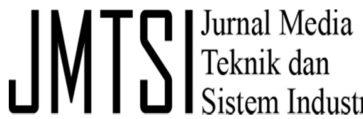

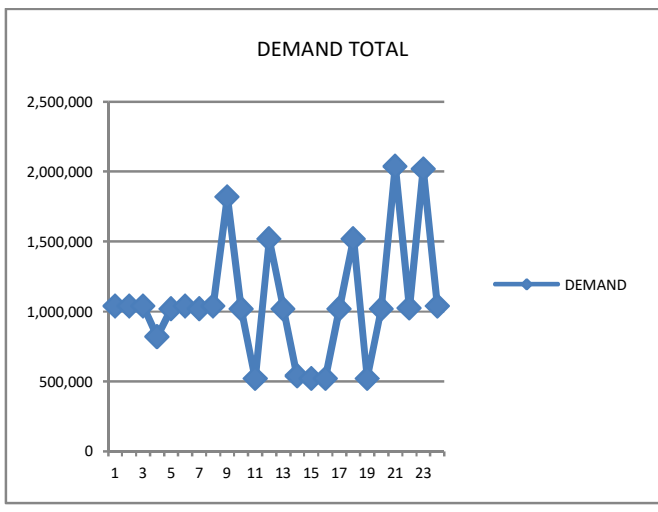

Gambar 3. Plot data demand plastik featherlock s brown

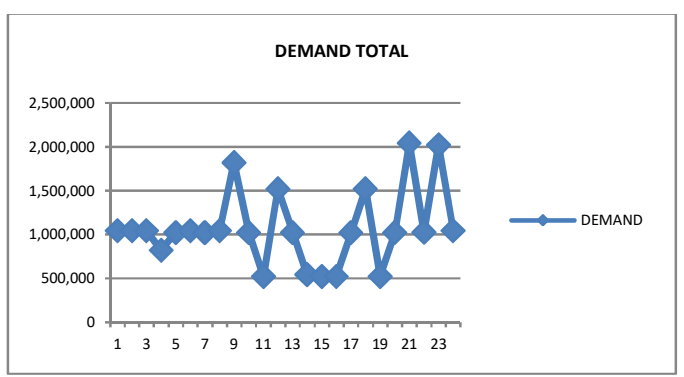

Gambar 4.Plot data demand total

\subsection{Pengolahan Data}

\subsubsection{Perhitungan Agregasi Demand}

a. Faktor Konversi

Data faktor koreksi yang digunakan dan data hasil faktor konversi tercantum pada tabel II dan III.

TABEL II

DATA FAKTOR KONVERSI

\begin{tabular}{|c|c|c|}
\hline Nama Produk & $\begin{array}{c}\text { Jml dlm } \\
\text { Satu Capti }\end{array}$ & $\begin{array}{c}\text { Harga } \\
\text { Per Pcs }\end{array}$ \\
\hline $\begin{array}{c}\text { Sendok } \\
\text { Deabetamil }\end{array}$ & 4 & 500 \\
\hline $\begin{array}{c}\text { Plastik } \\
\text { Featherlock S } \\
\text { Brown }\end{array}$ & 43 & 70 \\
\hline
\end{tabular}

TABEL III

DATA HASIL FAKTOR KONVERS

\begin{tabular}{|c|c|c|}
\hline \multicolumn{3}{|c|}{ Faktor Konversi Berdasarkan Harga } \\
\cline { 1 - 1 } Sendok Deabetamil & $70 / 500$ & 0.14 \\
\cline { 1 - 1 } FK $=$ & & \\
\cline { 1 - 2 } $\begin{array}{c}\text { Plastik Featherlock S } \\
\text { Brown }\end{array}$ & $500 / 500$ & 1 \\
\cline { 1 - 1 } FK $=$ & & \\
\hline
\end{tabular}

b. Demand Agregat

Data total demand agregat seperti yang tercantum pada tabel IV di bawah ini.

TABEL IV

Data Total Demand Agregat

\begin{tabular}{|c|c|c|c|}
\hline Thn & Bln & Periode & $\begin{array}{c}\text { Total } \\
\text { Demand } \\
\text { (pc) }\end{array}$ \\
\hline \multirow{12}{*}{2015} & JAN & 1 & 1005600 \\
\hline & FEB & 2 & 1005600 \\
\hline & MAR & 3 & 1005600 \\
\hline & APR & 4 & 802800 \\
\hline & MAY & 5 & 1002800 \\
\hline & JUN & 6 & 1005600 \\
\hline & JUL & 7 & 1002800 \\
\hline & AUG & 8 & 1005600 \\
\hline & SEP & 9 & 1802800 \\
\hline & OCT & 10 & 1002800 \\
\hline & NOV & 11 & 502800 \\
\hline & DEC & 12 & 1502800 \\
\hline \multirow{12}{*}{2016} & JAN & 13 & 1002800 \\
\hline & FEB & 14 & 505600 \\
\hline & MAR & 15 & 502800 \\
\hline & APR & 16 & 502800 \\
\hline & MAY & 17 & 1002800 \\
\hline & JUN & 18 & 1502800 \\
\hline & JUL & 19 & 502800 \\
\hline & AUG & 20 & 1002800 \\
\hline & SEP & 21 & 2005600 \\
\hline & OCT & 22 & 1003500 \\
\hline & NOV & 23 & 2002800 \\
\hline & $\mathrm{DEC}$ & 24 & 1005600 \\
\hline \multicolumn{3}{|c|}{$\sum$} & 25190300 \\
\hline
\end{tabular}

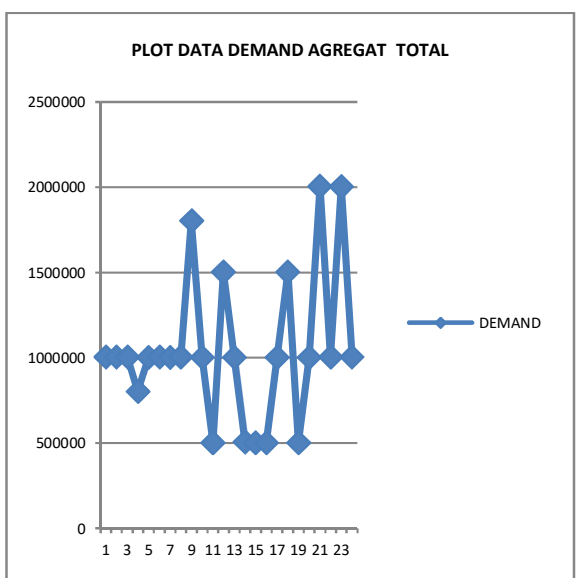

Gambar 4. Plot data demand agregat total 


\subsubsection{Peramalan}

Peramalan Double Exponensial Smoothing 2

Parameter Dari Holt

$\boldsymbol{S}_{\boldsymbol{t}}{ }=$ Smoothing/ Pemulusan pertama dari demand dengan parameter $\boldsymbol{\alpha}$

Rumus :

$S_{t}^{\prime}=\alpha \cdot X_{t}+(1-\alpha) \cdot S_{t-1}^{\prime}+b_{t-1}$

$\boldsymbol{b}_{\boldsymbol{t}}=$ Smoothing/ Pemulusan kedua dari demand dengan parameter $\gamma$

Rumus :

$b_{t}=\gamma\left(S_{t}-S_{t-1}\right)+(1-\gamma) b_{t-1}$

$F t=$ Forecasting (peramalan)

Rumus :

$F t=S^{\prime} t+b t(m)$

$\boldsymbol{e}_{\boldsymbol{t}}=\operatorname{Error}($ kesalahan perhitungan peramalan)

Rumus :

$e_{t}=$ Demand-Peramalan

$e_{t}=X t-F t$

$\left|\boldsymbol{e}_{\boldsymbol{t}}\right|=$ Harga mutlak dari et (Absoulot Error)

Rumus :

$\left|\boldsymbol{e}_{\boldsymbol{t}}\right|=$ Harga mutlak dari et (Absoulot Error)

$\boldsymbol{e}_{\boldsymbol{t}}{ }^{2}=$ Kuadrat error

Rumus :

$\boldsymbol{e}_{\boldsymbol{t}}{ }^{2}=$ Kuadrat error

1. Mencari $\mathbf{M E}=$ Mean Error (Rata-Rata Error)

Rumus :

$$
M E=\frac{\sum e_{t}}{n}
$$

2. Mencari MAE = Mean Absoulot Error (RataRata dari Harga Mutlak Eror)

Rumus :

$$
M A E=\frac{\sum\left|e_{t}\right|}{n}
$$

3. Mencari SSE

SSE = Sum Square Error (Jumlah Error Kuadrat)

$=$ Mencari MSE = Mean Square

Error (Rata-Rata dari Eror Kuadrat)

Rumus :

$$
M S E=\frac{\sum e_{t}^{2}}{n}
$$

4. Mencari $\mathbf{S D E}=$ Standar Deviasi Error

Rumus :

$$
S D E=\sqrt{\frac{\sum e_{t}^{2}}{n}}
$$

3.2.3 Proses Perencanaan Produksi Agregat

Data yang diperlukan untuk melakukan perencanaan produksi agregat adalah meliputi

\begin{tabular}{|c|c|c|}
\hline Inventori awal & $: 0$ & Unit \\
\hline Jml T.k langsung & $: 70$ & Org \\
\hline $\mathrm{Wb}$ & $: 0.01$ & $\begin{array}{l}\text { Jam } \\
\text { org,unit }\end{array}$ \\
\hline $\begin{array}{l}\text { Ongkos Reguler } \\
\text { Time }\end{array}$ & $: \operatorname{Rp} 285$ & Per unit \\
\hline Ongkos Over Time & : Rp 489 & Per unit \\
\hline Onkos Subkontrak & : Rp 713 & Per unit \\
\hline Ong. Hiring & : Rp 1500000 & Perorg \\
\hline Ong. Lay off & : Rp 2100000 & Per org \\
\hline Ong. Simpan & : Rp23 & $\begin{array}{l}\text { Per } \\
\text { unit.bln }\end{array}$ \\
\hline
\end{tabular}
data rencana produksi dan data ongkos. Adapun data-data tersebut adalah sebagai berikut:

$\begin{array}{lll}\text { Jam Kerja } & : 8 & \text { Jam } \\ \text { Maksimum Lembur } & : 25 \% & \text { Dari } \\ \text { Maksimum } & : 50 \% & \text { UPRT } \\ \text { subkontrak } & & \text { Dari } \\ \end{array}$

Berikut ini pada tabel $\mathrm{V}$ merupakan data permintaan 1 tahun yang akand atang yang diperoleh dari proses peramalan.

TABEL V

DATA HASIL PERAMALAN DOUBLE EXPONENTIAL SMOOTHING PARAMETER DARI HOLT
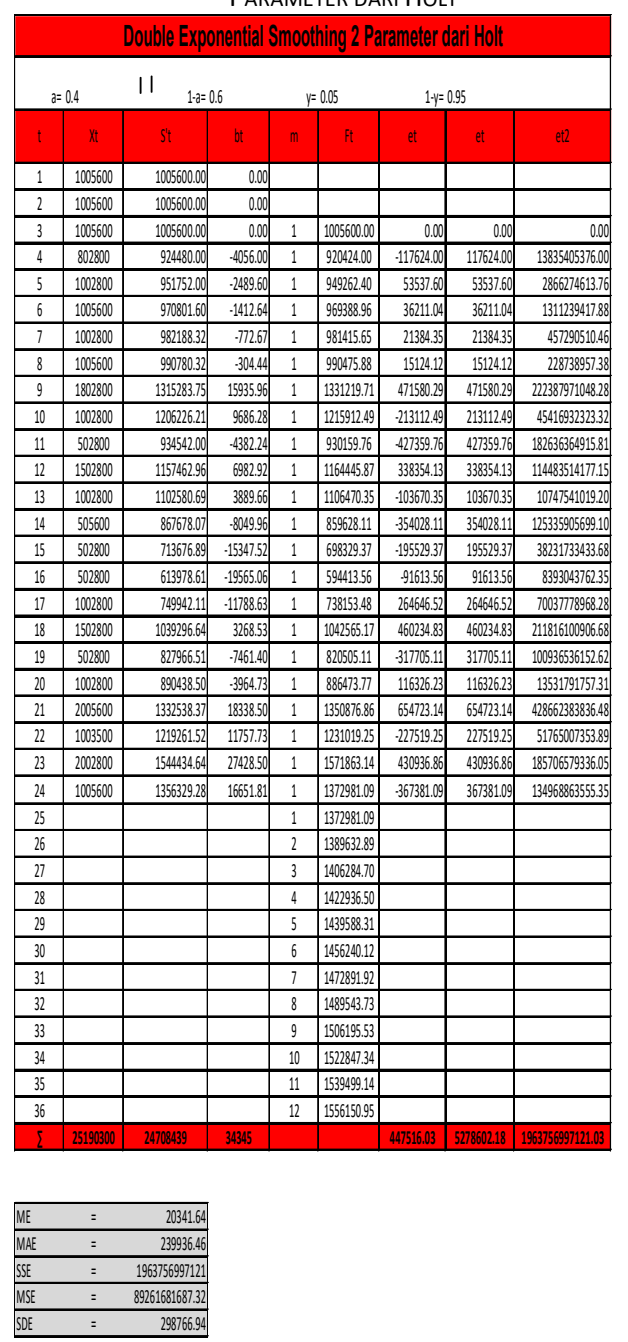


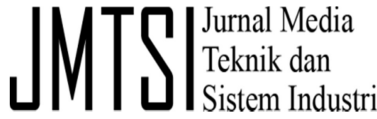

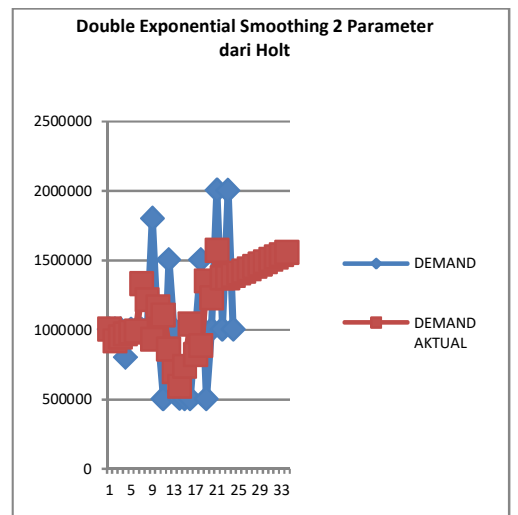

Gambar 5. Plot data hasil peramalan Exponential Smoothing2 Parameter dari Holt

TABEL VI

DATA HARI KERJA DAN PERMINTAAN

\begin{tabular}{|c|c|c|c|c|}
\hline Periode & Thn & Bulan & $\begin{array}{c}\text { Hari } \\
\text { Kerja }\end{array}$ & Demand \\
\hline 1 & \multirow{12}{*}{2017} & Jan. & 24 & 1372982 \\
\hline 2 & & Feb. & 26 & 1389633 \\
\hline 3 & & Maret & 27 & 1406285 \\
\hline 4 & & April & 26 & 1422937 \\
\hline 5 & & Mei & 26 & 1439289 \\
\hline 6 & & Juni & 26 & 1456241 \\
\hline 7 & & Juli & 26 & 1472892 \\
\hline 8 & & Agust. & 26 & 1489544 \\
\hline 9 & & Sept. & 20 & 1506196 \\
\hline 10 & & Okt. & 26 & 1522848 \\
\hline 11 & & Nov. & 26 & 1539500 \\
\hline 12 & & Des. & 27 & 1556151 \\
\hline \multicolumn{3}{|c|}{$\sum$} & 306 & 17574498 \\
\hline
\end{tabular}

o. Menghitung Rencana Produksi

$\Sigma \mathrm{RP}=\Sigma$ demand + safety stock - inventory awal

p. Menghitung reguler man hour $(\mathrm{RMH})$

$\mathrm{RMH}=\mathrm{jml}$ tenaga kerja $\mathrm{x}$ hari kerja $\mathrm{x}$ jam kerja

q. Menghitung Produksi Normal (UPRT)

Produksi Normal $=\frac{\mathrm{RMH}}{\text { Waktubaku }} \mathrm{X}$ Persen produktivitas

r. Menghitung kapasitas Produksi Normal (UPRT)

KAP produksi normal $=\frac{70 \times 24 \times 8}{0,1}$

s. Menghitung Inventory akhir Inventory akhir = UPRT- demand

t. Menghitung unit produksi over time(UPOT) Menghitung unit produksi over time(UPOT), atau lembur dilakukan jika produksi normal (UPRT) tidak dapat memenuhi permintaan. Dalam kata lain jika UPRT lebih besar dari
demand(UPRT >demand)tidak perlu melakukan UPOT.

$\mathrm{UPOT}=\mathrm{UPRT}-$ demand + Inventory akhir

u. Menghitung kapasitas unit produksi over time(UPOT)

Kapasitas UPOT $=25 \%$ x UPRT

v. Menghitung Subkontrak

Subkontrak dilakukan apabila kapasitas demand tidak terpenuhi meski sudah melakukan lembur (UPOT).

Subkontrak = Demand - inventory awal UPRT - UPOT

w. Menghitung kapasitas Subkontrak Kapasitas Subkontrak $=50 \%$ x UPOT

x. Menghitung ongkos produksi normal

Tot. ongkos UPRT $=\sum$ UPRT $\mathrm{x}$ ongkos UPRT

y. Menghitung ongkos produksi lembur

Tot. ongkos UPOT $=\sum$ UPOT $\mathrm{x}$ ongkos UPOT

z. Menghitung ongkos simpan

Tot. ongkos simpan $=\sum$ inventori akhir $\mathrm{x}$ ongkos inventori akhir

aa. Menghitung ongkos total produksi

Total produksi ongkos $=$

$=$ ongkos produksi normal + ongkos produksi lembur + ongkos simpan

TABEL VII

DATA HASIL PERHITUNGAN PRODUKSI AGREGAT TENAGA KERJA TETAP

\begin{tabular}{|c|c|c|c|c|c|c|c|c|}
\hline PERIODE & HARU KERIA & DEMAND & RMAH & URTT & UPOT & SUB YOUTRAK & IWEETOR AHAR & TOTA PPOOUKS \\
\hline BUAN & HARR & UNIT & HARI & UNT & UNT & UVIT & UNT & WVIT \\
\hline 1 & 24 & 1379882 & 13440 & 1653467 & & & 90485 & 1463367 \\
\hline 2 & 26 & 13906533 & 14550 & 1585422 & & & 2886714 & 1585542.2 \\
\hline 3 & 27 & 1466285 & 15120 & 1664640 & & & 526389 & $1664+0$ \\
\hline 4 & 26 & 142937 & 14500 & 1585422 & & & 688874 & 1585542.2 \\
\hline 5 & 26 & 1439289 & 14500 & 158542 & & & 835007 & 1555422 \\
\hline 6 & 26 & 1456241 & 14500 & 15854212 & & & 964189 & 155542.2 \\
\hline 1 & 26 & 1477892 & 14560 & 1585422 & & & 107619 & 155542.2 \\
\hline 8 & 26 & 1485544 & 14500 & 15854212 & & & 1177597 & 155542.2 \\
\hline 9 & 20 & 15661966 & 11200 & 1219556 & & & 885557 & 12195556 \\
\hline 10 & 26 & 1522848 & 14500 & 1585422 & & & 948531 & 155542.2 \\
\hline 11 & 26 & 1539500 & 14500 & 1585422 & & & 994453 & 158542.2 \\
\hline 12 & 27 & 1556151 & 15120 & 1664640 & & & 108402 & 166460 \\
\hline I & 306 & 1757498 & 171330 & 18659200 & & 0 & & 18659200 \\
\hline
\end{tabular}

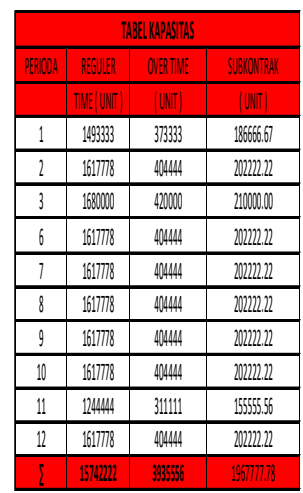


3.2.4 Proses disagregasi dengan proporsi

1. Menghitung \% Proporsi

$\%$ Proporsi $=\frac{\text { Total demand agregat end item }}{\text { Total } \text { demand agregat }} \times 100 \%$

TABEL VIII

HASIL PERSEN PROPORSI

\begin{tabular}{|c|c|c|}
\multicolumn{2}{c}{ HASIL PERSEN PROPORSI } \\
\hline End Item & $\%$ Proporsi & $\begin{array}{c}\text { Faktor } \\
\text { Konversi }\end{array}$ \\
\hline Sendok Deabetamil & $0,36 \%$ & 0,14 \\
\hline $\begin{array}{c}\text { Plastik Featherlock } \\
\text { S Brown }\end{array}$ & $99,64 \%$ & 1 \\
\hline
\end{tabular}

\section{Menghitung forecast demand}

End item $_{\mathrm{t}}=$ demand aktual X \% Proporsi

Dengan perhitungan ini maka akan di dapat demand forcast aktual seperti tabel IX dibawah ini.

TABEL IX DATA DEMAND FORECAST ACTUAL

\begin{tabular}{|c|c|c|c|}
\hline Periode & $\begin{array}{c}\text { Sendok } \\
\text { Deabetamil }\end{array}$ & $\begin{array}{c}\text { Plastik } \\
\text { S Brown }\end{array}$ & Jumlah \\
\hline Jan & 4943 & 1368040 & 1372983 \\
\hline Feb & 5003 & 1384631 & 1389634 \\
\hline Mar & 5063 & 1401223 & 1406286 \\
\hline Apr & 5123 & 1417815 & 1422938 \\
\hline May & 5182 & 1434108 & 1439290 \\
\hline Jun & 5243 & 1450999 & 1456242 \\
\hline Jul & 5303 & 1467590 & 1472893 \\
\hline Aug & 5363 & 1484182 & 1489545 \\
\hline Sep & 5423 & 1500774 & 1506197 \\
\hline Oct & 5483 & 1517366 & 1522849 \\
\hline Nov & 5543 & 1533958 & 1539501 \\
\hline Dec & 5603 & 1550549 & 1556152 \\
\hline$\sum$ & 63275 & 17511235 & 17574510 \\
\hline
\end{tabular}

3. MenghitungMaster Schedule

Data yang digunakan untuk dapat menghitung master schedule adalah data total perencanaan produksi yang di kali proporsi rata-rata lalu di bagi faktor konversi masingmasingend item, jelasnya dapat menggunakan rumus seperti dibawah ini:

MS $=\frac{\text { Total Produksi } x \text { proporsi rata-rata end item }}{\text { faktor konversi } \text { end item }}$

Dengan menggunakan rumus diatas maka di dapat master schedule seperti terlihat pada tabel X di bawah ini.
TABEL X

HASIL MASTER SCHEDULE

\begin{tabular}{|c|c|c|c|}
\hline \multirow{2}{*}{ Periode } & \multirow{2}{*}{$\begin{array}{c}\text { Total } \\
\text { Prod }\end{array}$} & \begin{tabular}{c} 
Sendok \\
\cline { 3 - 4 }
\end{tabular} & $\begin{array}{c}\text { Eeabetamil } \\
\text { Featherlock } \\
\text { Brown }\end{array}$ \\
\hline 1 & 1463467 & 37632 & 1458198 \\
\hline 2 & 1585422 & 40768 & 1579715 \\
\hline 3 & 1646400 & 42336 & 1640473 \\
\hline 4 & 1585422 & 40768 & 1579715 \\
\hline 5 & 1585422 & 40768 & 1579715 \\
\hline 6 & 1585422 & 40768 & 1579715 \\
\hline 7 & 1585422 & 40768 & 1579715 \\
\hline 8 & 1585422 & 40768 & 1579715 \\
\hline 9 & 1219556 & 31360 & 1215165 \\
\hline 10 & 1585422 & 40768 & 1579715 \\
\hline 11 & 1585422 & 40768 & 1579715 \\
\hline 12 & 1646400 & 42336 & 1640473 \\
\hline
\end{tabular}

\subsubsection{Master Production Schedule}

Tabel XI di bawah ini menunjukan hasil perhitungan master production schedule (MPS).

TABEL XI

HASIL PeRHITUNGAN MPS

\begin{tabular}{|c|c|c|c|c|c|c|c|c|c|c|c|c|c|}
\hline \multicolumn{14}{|c|}{ MASTER PRODLCTIONSSHEDULE } \\
\hline DEECPPTION & & & & & & & & & \multicolumn{5}{|c|}{ DIF } \\
\hline $\mathbb{T E}$ & SEDDOK & ABEEAMIII & & & & & & & \multicolumn{5}{|c|}{ PTF } \\
\hline IEADTME & & & & & & & & & & \multicolumn{4}{|c|}{ SHEEYYSTOCK:D } \\
\hline PEROOE & PASTDU & 1 & 1 & 3 & 4 & i & 6 & 7 & 8 & 9 & 10 & 11 & 12 \\
\hline FPRECAST & & 9496 & $5 M_{3}$ & 563 & 512 & 502 & 242 & 530 & 5263 & 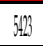 & 5880 & 5313 & 5010 \\
\hline ACTUADEAMAD & & 2000 & & & & & & & & & & & \\
\hline$P A B$ & 0 & 3669 & $68: 42$ & 1072 & 11132 & 17065 & 2121240 & 29748 & 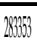 & 3020 & 34772 & 39000 & $4 / 6233$ \\
\hline $\mathbb{A P}$ & & 2000 & & & & & & & & & & & \\
\hline MASTERSCHEDUE & & 3762 & $47 / 80$ & 43256 & $47 / 60$ & 4078 & $47 / 60$ & 47768 & $40 / 68$ & 31300 & 40768 & 40760 & 43366 \\
\hline
\end{tabular}

\begin{tabular}{|c|c|c|c|c|c|c|c|c|c|c|c|c|c|}
\hline DECPRPTION & & & & & & & & & & & \multicolumn{3}{|c|}{ DIF } \\
\hline $\mathbb{I T E}$ & \multicolumn{10}{|c|}{ PLLASIKKEEATHERLCOKSBROWN } & \multicolumn{3}{|c|}{ PTF } \\
\hline LEADTINE & & & & & & & & & & & \multicolumn{3}{|c|}{ SAEREYGTOCK:D } \\
\hline PERIODE & PASTDUE &. & 2 & 3 & 4 & i & 6 & 7 & 8 & 9 & 10 & 11 & 12 \\
\hline EASTI & & 1360040 & 1384621 & 140122 & 147875 & 113All & 14500909 & 14650 & 1841812 & 150077 & 1517360 & 153358 & 150606 \\
\hline ACTUADEBAID & & 50000 & & & & & & & & & & & \\
\hline PAB & 0 & 91580 & 13242 & 5449. & 66039 & 83998 & 900711 & 102839 & 116071 & 08260 & 9:16i11 & 99086 & $1007 \%$ \\
\hline $\mathbb{A P}$ & & 95690 & & & & & & & & & & & \\
\hline FRSCHEDUE & & 148708 & 159711 & 160473 & $1507 / 15$ & 159715 & 159715 & 157915 & 159715 & 12151616 & $197 / 15$ & 159715 & 473 \\
\hline
\end{tabular}




\subsubsection{Rought Cut Capacity Planning (RCCP)}

Tahapan-tahapan yang harus dilakukan dalam proses RCCP adlaah sebgai berikut:

1. Menentukan Routhing Sheet

Menghitung routing sheet menggunakan persamaan rumus pada BAB III, yaitu:

Standar Hours $=\frac{\text { Run Time }+\left\{\left\{\frac{\text { Setup Times }}{\text { lot size }}\right\}\right.}{3600}$

Untuk contoh perhitungan diketahui sebelumnya bahwa runtimedidapat dari OPC, sedangkan untuk setup Time dan Lotsizedidapat adari data ketentuan perusahaan itu sendiri, berikut contoh perhitungannya:

Untuk mencari standar hours pada operasi yang lain menggunakan rumus yang sama, hingga didapat tabel XII dan XIII seperti dibawah ini.

TABEL XII

ROUTING SHEET SENDOK DEABETAMIL

\begin{tabular}{|c|c|c|c|c|c|c|}
\hline \multicolumn{7}{|c|}{ ROUTING SHEET SENDOK DEBBEAAMIL } \\
\hline \multirow{2}{*}{ TIEM } & \multirow{2}{*}{ PROSSS } & \multirow{2}{*}{$\begin{array}{l}\text { WORY SARTION } \\
\text { IML }\end{array}$} & \multirow{2}{*}{\begin{tabular}{|l|} 
RUNTME \\
detilk \\
\end{tabular}} & \multirow{2}{*}{\begin{tabular}{|l} 
SETUPTIME \\
detik \\
\end{tabular}} & \multirow{2}{*}{\begin{tabular}{|l|} 
LOTSSIE \\
CAPTYY \\
\end{tabular}} & \multirow{2}{*}{$\begin{array}{c}\text { SANDAR HOUR R } \\
\text { IAMI } \\
\end{array}$} \\
\hline & & & & & & \\
\hline PROOELINE POIYTAN5 $8 \mathrm{gr}$ & Timbangs & 1 & 0.2 & 0 & 4 & 0.00005 \\
\hline \multirow{2}{*}{ PIGWEWWARAN puthih 2 gr } & Timbang & 1 & 0.2 & 0 & 4 & 0.00005 \\
\hline & Addk & 1 & 0.2 & 0 & 4 & 0.00006 \\
\hline \multirow[t]{2}{*}{ PENEEESAAN } & Timbang & 1 & 0.1 & 0 & 4 & 0.00003 \\
\hline & Cetak|(Moudinges) & 10 & 0.007 & 120 & 4 & 0.0034 \\
\hline \multirow{3}{*}{$\begin{array}{l}\text { PROSESPPROOUKSI } \\
\text { SEADOK DEBBEAAMIL }\end{array}$} & Periks & 10 & 0.007 & 0 & 4 & 0.00000 \\
\hline & dipotong & 10 & 0.007 & 0 & 4 & 0.00000 \\
\hline & Kemas & 20 & 0.2 & 0 & 4 & 0.0005 \\
\hline
\end{tabular}

\begin{tabular}{|c|c|c|c|c|c|c|}
\hline \multicolumn{7}{|c|}{ ROUTING SHEET PLSTTK FEATHERLOCCK S BBOWN } \\
\hline \multirow{2}{*}{ ITEM } & \multirow{2}{*}{ PROSES } & WORK STATION & RUNTIMU: & SETUPTIME & LOTS12: & STANDOR HOUYS \\
\hline & & IML. & detik & detik & CAPTT & AM \\
\hline PROPELINEPOIYTAN03gr & Timbang & 1 & 0.2 & & 43 & 0.00005 \\
\hline \multirow{2}{*}{ PGGEN WARNA putho, gr } & Timbang & 1 & 0.2 & & 43 & 0.00005 \\
\hline & Aduk & 1 & 0.2 & & 43 & 0.00005 \\
\hline \multirow[t]{2}{*}{ PENVELESAAN } & Timbang & 1 & 0.1 & & 43 & 0.00003 \\
\hline & Cetak|(Mouddings) & 10 & 0.0002 & 120 & 43 & 0.00078 \\
\hline \multirow{3}{*}{$\begin{array}{l}\text { ProSSESPROOUSSI } \\
\text { SENDOK DeEBEAMMLL }\end{array}$} & Periksa & 10 & 0.007 & & 43 & 0.00000 \\
\hline & dipotong & 10 & 0.007 & & 43 & 0.00000 \\
\hline & Kemas & 20 & 0.2 & & 43 & 0.00005 \\
\hline
\end{tabular}

2. Menentukan Rought Cut Capacity Planning (RCCP)

\section{RCCP = MasterSchedule x Standard Hours}

Untuk mencari RCCP produk sendok deabetamil dan plastik featherlock s brown pada work station dan periode selanjutnya menggunakan rumus yang sama, hingga didapat tabel-tabel dibawah ini.

\section{JMTS}

TABEL XIV

BILL OF CAPACITY (BOC)

\begin{tabular}{|c|c|c|}
\hline \multicolumn{3}{|c|}{ Bill Of Capacity (boc) } \\
\hline \multirow{2}{*}{$\begin{array}{c}\text { Work } \\
\text { Station }\end{array}$} & \multicolumn{2}{|c|}{ Standar Hours (jam) } \\
\cline { 2 - 3 } & S.Deabetamil & Plastik Feather \\
\hline 1 & 0.0002 & 0.0002 \\
\hline 10 & 0.0083 & 0.0008 \\
\hline 20 & 0.00005 & 0.00005 \\
\hline
\end{tabular}

TABEL XV

MASTER SCHEDULE

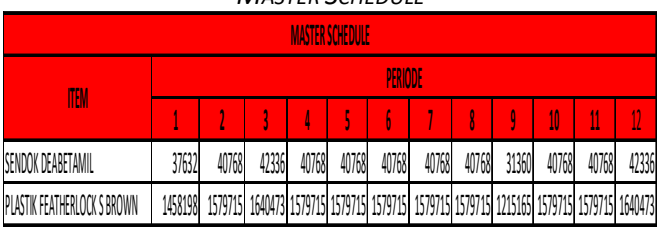

TABEL XVI

RCCP WS 1

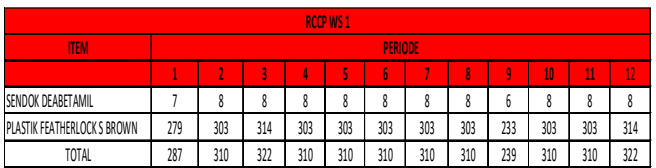

TABEL XVII

RCCP Ws 10

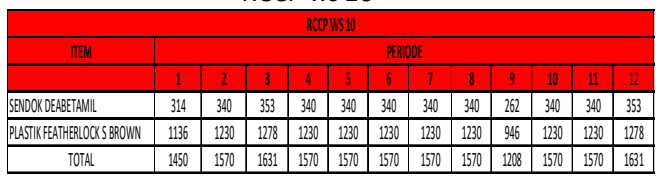

TABEL XVIII

RCCP Ws 20

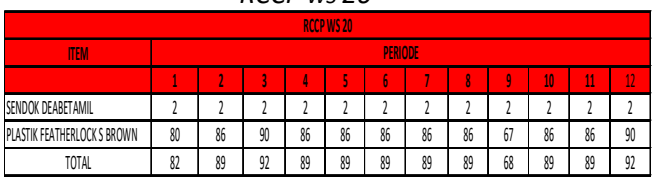

3. Menentukan kapasitas yang dibutuhkan

Untuk menghitung kapasitas yang dibutuhkan dilakukan dengan menjumlahkan total RCCP dari tiap work station, jumlah total RCCP pada tiap ws dapat dilihat pada tabel sebelumnya. Jelasnya dapat di lihat pada tabel XIX di bawah ini.

TABEL XIX

KAPASITAS KEBUTUHAN

\begin{tabular}{|c|c|c|c|c|c|c|c|c|c|c|c|c|}
\hline \multirow{3}{*}{ WS } & \multicolumn{12}{|c|}{ KEBUTUAANKAPASTAS } \\
\hline & \multicolumn{12}{|c|}{ PEROOEE } \\
\hline & 1 & 2 & 3 & 4 & 5 & 6 & 1 & 8 & 9 & 10 & 11 & 12 \\
\hline 1 & 287 & 310 & 322 & 310 & 310 & 310 & 310 & 310 & 239 & 310 & 310 & 322 \\
\hline 10 & 1450 & 150 & 1631 & 150 & 1550 & 150 & 150 & 150 & 1208 & 150 & 1570 & 1631 \\
\hline 20 & 82 & 89 & 92 & 89 & 89 & 89 & 89 & 89 & 68 & 89 & 89 & 92 \\
\hline TOTAL & 1818 & 1900 & 2005 & 1970 & 1970 & 1970 & 1970 & 1970 & 1515 & 1970 & 1970 & 2045 \\
\hline
\end{tabular}


4. Menentukan kapasitas yang tersedia

Untuk menghitung kapasitas yang tersedia menggunakan persamaan rumus pada BAB III, yaitu sebgai berikut:

Kapasitas tersedia $=$ Jam kerja $\mathrm{x}$ Hari kerja $\mathrm{x}$ Tenaga kerja

Tabel III.20 Data jam kerja, hari kerja dan jumlah tenaga kerja

TABEL XX

DATA JAM KERJA, HARI KERJA, DAN JUMLAH TENAGA KERJA

\begin{tabular}{|c|c|c|c|}
\hline IAM KERA & JMLTKKWS1 & JMLTKWS 10 & JMLTKWW 20 \\
\hline 8 & 10 & 20 & 40 \\
\hline
\end{tabular}

\begin{tabular}{|l|l|l|l|l|l|l|l|l|l|l|l|l|}
\hline HAR I KERA & 24 & 26 & 27 & 26 & 26 & 26 & 26 & 26 & 20 & 26 & 26 & 27 \\
\hline
\end{tabular}

Untuk mengetahui kapasitas tersedia pada periode berikutnya menggunakan rumus yang sama. Adapun jelasnya dapat dilihat pada tabel XXI berikut ini.

TABEL XXI

KAPASITAS TERSEDIA

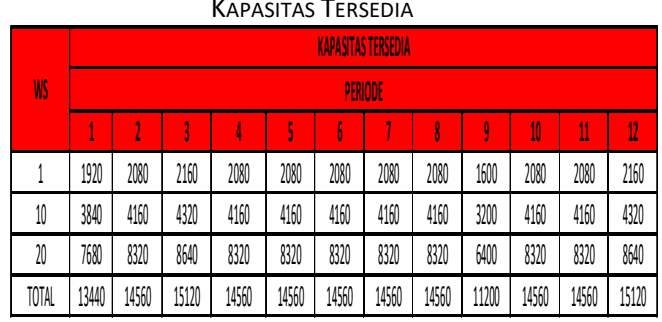

RCCP ditampilkan dalam suatu diagram yang dikenal sebagai Load Profile untuk menggambarkan kapasitas yang dibutuhkan versus kapasitas yang tersedia.Load Profile didefinisikan sebagai tampilan dari kebutuhan kapasitas di waktu mendatang berdasarkan pesanan-pesanan yang direncaanakan dan dikeluarkan sepanjang suatu periode waktu tertentu.Validasi pada RCCP dikatakan layak apabila kapasitas yang dibutuhkan semuanya dapat dipenuhi oleh kapasitas tersedia. Adapun perbandingan antara kapasitas kebutuhan dan kapasitas tersedia pada permasalahan kali ini dapat dilihat pada gambar 6,7 dan 8 berikut ini.

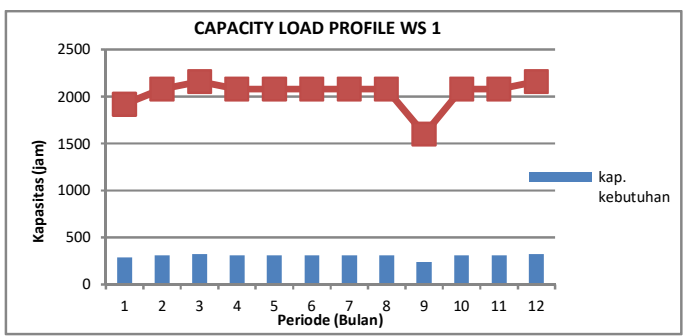

Gambar 6. Grafik load profile WS 1

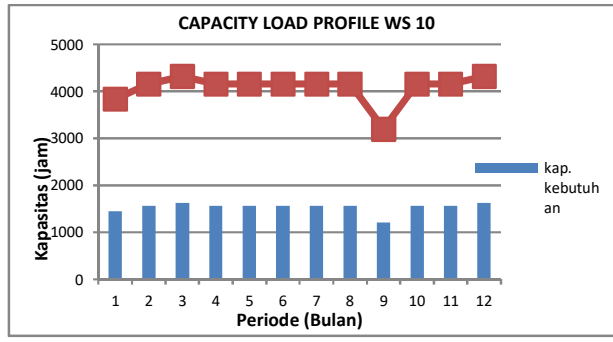

Gambar 7. Grafik load profile WS 10

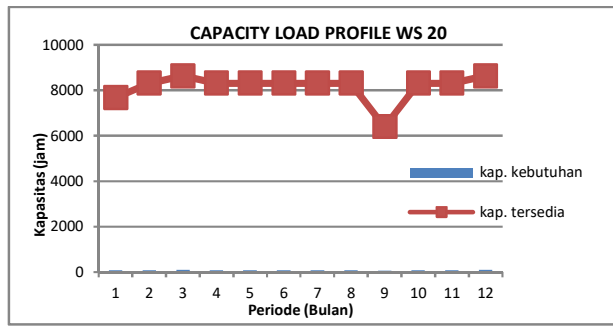

Gambar 8. Grafik load profile WS 20

\section{ANALISIS DAN PEMBAHASAN}

4.1 Disagregasi dan Master productions schedule (MPS)

Proses disagregasi adalah proses pemecahan kembali dari data yang sebelumnya telah di agregatkan yaitu dengan menggunakan proporsi hingga di dapat actual demand yang diramalkan dari kedua produk yang diteliti. Dari hasil perhitungan berdasarkan teori didapat bahwa hasil perhitungan master schedule lebih besar dai hasil forcast demand. Hal ini berarti bahwa permintaan sepanjang tahun 2017 dapat terpenuhi.

Berdasarkan perhitungan yang tampak pada MPS, dapat dilihat bahwa nilai PAB relatif stabil dan besar, hal ini berarti permintaan yang ada dapat terpenuhi sepenuhnya. Pada MPS sendok deabetamil actual demandhanya ada pada bulan Januari saja sebanyak 20,000 pcs, maka didapat ATP sebesar 17,632 pcs, hal ini berarti jumlah produk yang dapat perusahaan janjikan hanya sebesar 17,632 pcs dari total actual demand sebanyak 20,000 pcs, dengan kata lain jumlah yang dijanjikan masih kurang sebesar 2,368 pcs, maka perusahaan harus dapat memenuhin permintaan actual demand sebanyak 20,000 pcs dengan menambah sebanyak 2,368 pcs dengan cara menggunakan jam lembur.

Begitupun pada MPS plastik featherlock $s$ brown actual demand hanya ada pada bulan Januari saja sebanyak 500,000 pcs, maka didapat ATP sebesar 958,198 pcs, hal in berarti jumlah produk yang dapat perusahaan janjikan dapat terpenuhi 


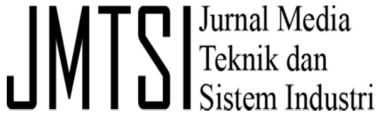

Sedangkan pada periode selanjutnya tidak ada ATP atau jumlah yang harus perusahaan janjikan terhadap konsumen dikarenakan actual demand belum ada. Dalam format MPS inipun DTF dan PTF belum di tentukan dikarenakan perusahaan belum mempunyai atau menggunakan MPS dalam penjadwalan produksinya, begitupun dengan lead time, tidak ada lead time dikarekan perusahaan tidak menggunakan subkontrak atau pemesanan produk end item terhadap perusahaan lain.

\subsection{Rought Cut Capacity Planning (RCCP)}

Kegunaan RCCP adalah untuk menganalisis kelayakan MPS denagan pertimbangan kapasitas perusahaan dan merekomendasikan revisi pada MPS jika setelah melakukan perhitungan pada RCCP didapakan hasil beberapa periode tidak dapat terpenuhi oleh kapasitas perusahaan hal ini dilakukan agar proses produksi sesuai dengan kaspasitas yang mampu perusahaan lakukan. Adapaun format RCCP yang penulis gunakan adalah menggunakan kapasitas jam tersedia, jumlah jam yang dapat perusahaan lakukan dalam proses produksinya. Setelah proses perhitungan RCCP dilakukan maka didapat kapasitas tersedia mampu memenuhi kapasitas yang dibutuhkan, hal ini dapat dilihat pada grafik yang di sebut load profil capacity.

Pada grafik load profil work station 1 dapat dilihat bahwa jumlah jam tersedia dapat memenuhi jam kebutuhan. Begitupun pada work station 10 dan work station 20 . Dengan melihat kapasitas jam tersedia yang mampu memenuhi kapasitas kebutuhan maka perusahaan tidak akan mengalami kendala selama menjalan produksi untuk periode Januari sampai dengan Desember 2017 ini. Bagian ini merupakan analisa mengenai hasil yang didapat. Hindari penggunaan sitasi dan diskusi yang berlebihan tentang literatur yang telah dipublikasikan. Kemukakan arti penting dari hasil penelitian dan implikasinya

\section{KESIMPULAN}

1. Proses perencanaan produksi ini menggunakan metode tenaga kerja tetap sesuai kebijakan P.T. Arwina Triguna Sejahtera. Dengan kapasitas Reguler Man Hour (RMH) sebanyak 171360 jam, perusahaan dapat memenuhi permintaan yang ada untuk periode Januari sampai dengan Desember 2017 sebanyak 18.659.200 pcs.

2. Semua permintaan dapat dijadwalkan dengan baik tanpa ada kemunduran jadwal. Untuk mengetahu ikelayakan MPS dalam mengelola penjadwalan dihitung RCCP dengan format kapasitas jam tersedia. Hasilnya didapat MPS untuk kedua Produk ini layak untuk dilakukan.

\section{REFERENSI}

[1] Frangklin G. moore/ Thomas E. Hendrick “ Manajemen Produksi dan Operasi 2" remadja Karya CV. 1986

[2] Volman/Berry/whybark/Jacobs "manufacturing planning and control for supply chain management", Text Book. 1988

[3] Anandita, Mutia "Perencanaan Produksi Dan Penentuan Jadwal Induk Produksi Roti Diperusahaan Industri Hidup Baru Pada Pemasaran Daerah Dengklok”, Bandung, 2007

[4] Laboratorium Sistem Produksi. Laporan Praktikum Sistem Produksi. Cianjur: UNSUR. 2011

[5] Handoko, T. Hani. Dasar-dasar manajemen produksi dan Operasi. BPFE-UGM, edisi 6, Yogyakarta. 1984

[6] Baroto, Teguh. Perencanaan dan Pengendalian Produksi. Ghalia Indonesia. Edisi 1. Jakarta. 2002

[7] Heizer, Jay dan Render, Barry. Prinsip-Prinsip Manajemen Operasi. Salemba Empat. Jakarta. 2001

[8] Heizer, Jay dan Render, Barry. Manajemen Operasi. Salemba Empat. 2008

[9] Pangestu Subagyo. Forecasting (Konsep dan Aplikasi). BPFE. Yogyakarta. 1999

[10] Subagyo Pangestu. Forecasting: Konsep dan Aplikasi. Edisi Kedua. BPFE. Yogyakarta. 1986

[11] Gaspersz, Vincent. Production Planning and Inventory Control. PT. Gramedia Pustaka Utama. Jakarta. 2004

[12] Kusuma, Hendra. Perencanaan dan Pengendalian Produksi. Edisi Pertama. ANDI. Yogyakarta. 1999.

[13] Sofyan Assauri. Teknik dan Metode Peramalan. LPFE UI. Jakarta. 1991 